\author{
Review Article
}

\title{
NIMBA (AZADIRACHTA INDICA) PRATISARANEEYA TEEKSHNA KSHARA: A COMPREHENSIVE REVIEW
}

\section{Manjunath.C.M1*, M.N.Hiremath², Raghuveer ${ }^{3}$}

${ }^{*}$ P.G. Scholar, ${ }^{2}$ Professor \& HOD, Department of Shalya Tantra, Ashwini Ayurvedic Medical College and P.G. Centre, Davanagere, Karnataka, India.

${ }^{3}$ Associate Professor \& HOD, Department of Rasashastra and Bhaishajya Kalpana, Ashwini Ayurvedic Medical College and P.G. Centre, Davanagere, Karnataka, India.

\section{Article info}

Article History:

Received: 01-10-2021

Revised: 15-10-2021

Accepted: 02-11-2021

\section{KEYWORDS:}

Arshas, Haemorrhoids, Pratisaraneeya teekshna kshara.

\begin{abstract}
Ayurveda promises, a disease free, happy and long life. Among the eight branches of Ayurveda, each branch consists of enormous knowledge from basic concepts up to critical health care strategies. Shalya tantra a prime branch in Astanga Ayurveda is the rich in many aspects of modern surgical concepts. This branch has immense potential to belt the solution of many challenging and unresolved complicated surgical ailments. Acharya Sushruta the pioneer in the field of surgery described four principles therapeutic types in the management of Arshas i.e., Bheshaja, Kshara karma, Agni Karma and Shastra Karma. Ayurvedic approach especially Kshara Karma stood for better than modern therapeutic option in terms of safety, easy, low cost, devoid of post operative complications and can be done as OPD procedure with minimal set up. Nimba pratisaraneeya kshara has been mentioned throughout the classical literature for Arsha, described as an Upakrama and is substitute for surgical procedure. Nimba pratisaraneeya teekshna kshara which is having antibacterial, antiviral and antifungal properties and is specially told by Acharya Sushruta. It can be successfully used in the management of Ardra Arshas without any post operative complications. Pratisaraneeya kshara is external application of Kshara whereas internal use of Kshara is known as Paniya kshara. Acharya Dalhana, the commentator of Sushruta explained that the substance which produces Shodhana of bodily Dosha, Dhatu, Maladi because of its Ksharana action is called Kshara. It is known as Kshara (alkali) also because of its corrosive nature (Ksharana) Kshara is having benefits like Chedana, Bhedana, Lekhana, Shodhana and Ropana properties with early hemostasis and total eradication of infection, so that it reduces recurrence, helps for the wound healing and also the duration of treatment is less. Though many researchers have been carried on Nimba till date, this review is done to highlight the significance of Kshara property in Nimba along with its therapeutic use.
\end{abstract}

\section{INTRODUCTION}

Acharya Sushruta has included Arshas under Asta Mahagadas ${ }^{[1]}$. Arshas are characterised by Mrudu, Prasruta, Avagada and Uchhrut[2]. Arshas co-related with haemorrhoids are the vericosities of the tributeries of the haemorrhoidal vein.

\section{Access this article online}

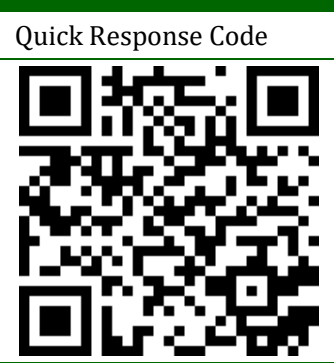

At least $5 \%$ of the general population suffers from haemorrhoids and the incidence apparently increases with age. At least 50 to $60 \%$ of the people over the age of 50 have some degree of haemorrhoids ${ }^{[3]}$. Bleeding is the cardinal sign of internal haemorrhoids, in classic it is one of the main symptoms in $1^{\text {st }}$ and $2^{\text {nd }}$ degree haemorrhoids ${ }^{[4]}$.

The effect of Kshara is praised so much that it can replace Shastra Karma since it does the Chedana, Bhedana, Lekhana karma without help of Shastra. Nimba pratisaraneeya kshara[5] having properties like Sheeta veerya, Tikta and Kashaya rasa acts on haemorrhoids by cauterising the pile mass, due to its 
Teekshna Kshara guna and coagulates protein in haemorrhoidal plexus.

The present therapeutic modalities like sclerotherapy, cryosurgery, rubber band ligation, infra red photo coagulation etc, needs high cost sophisticated instruments. Even though these are simple procedures, further they have their own disadvantages. In such conditions the alternative is Kshara karma procedure that gives relief and less post operative pain.

Neem tree (Azadirechta Indica) belongs to the family Meliaceae which is found in abundance in tropical and semitropical regions. It is indicated in Jwara, Kushta, Krimi, Prameha, Vrana, Kasa, Chardi, Visha roga, Arsha, Gulma, Kandu, Netra roga etc. The parts used from Nimba are root bark, stem bark, gum, fruit, flower, leaves, seeds and seed oil. Nimba having many synonyms like Arista, Pichumanda, Hinguniryasa, Tikta, Sutika, Niyamana, Puyari, Chardana, Sukapriya, Neta, Malaka, Prabhadra, Kakaphala, Varatikta,
Varatwacha. Nimba[6] is available in different varieties like Nimba (Azadirachta Indica), Maha nimba (Melia azadirach), Parvata Nimba (Alianthus exelsa).

\section{Properties of $\mathbf{N i m b a [ 7 ]}$}

\section{Rasa Panchakas}

- Rasa-Tikta, Kashaya

- Guna- Laghu, Ruksha

- Virya-Sheetha

- Vipaka-Katu

- Doshaghna-Kapha-pittahara

- Karma- Deepana, Grahi, Krimighna, Netrya, Madhumehaghna.

\section{Indications}

Jwara, Prameha, Kasa, Chardi, Arsha, Gulma, Kandu, Netra roga, Krimi, Kushta

\section{Part used}

Root bark, stem bark, gum, fruit, flower, leaves, seeds, seed oil.

Table 1: Therapeutic Uses of Nimba

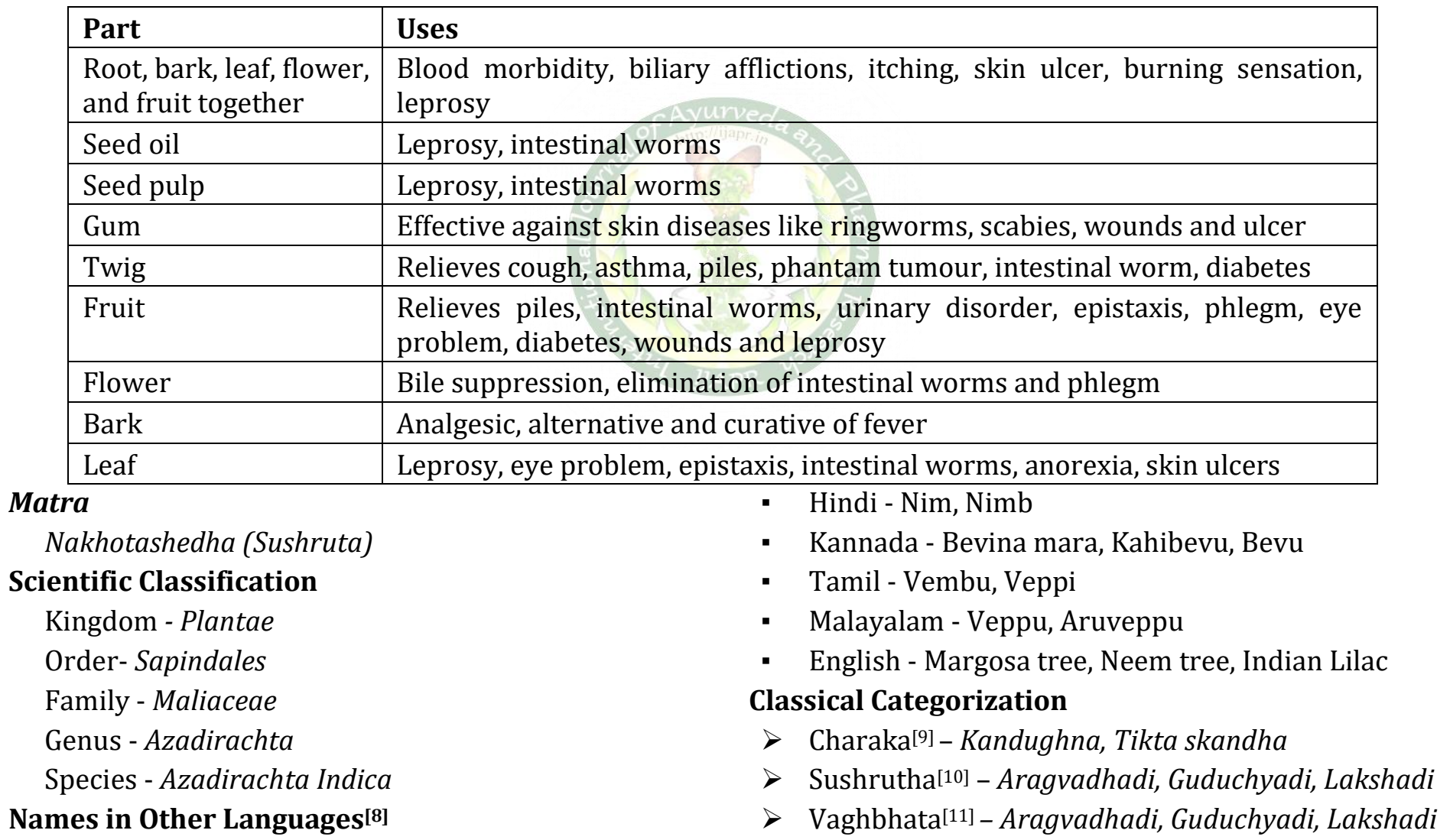

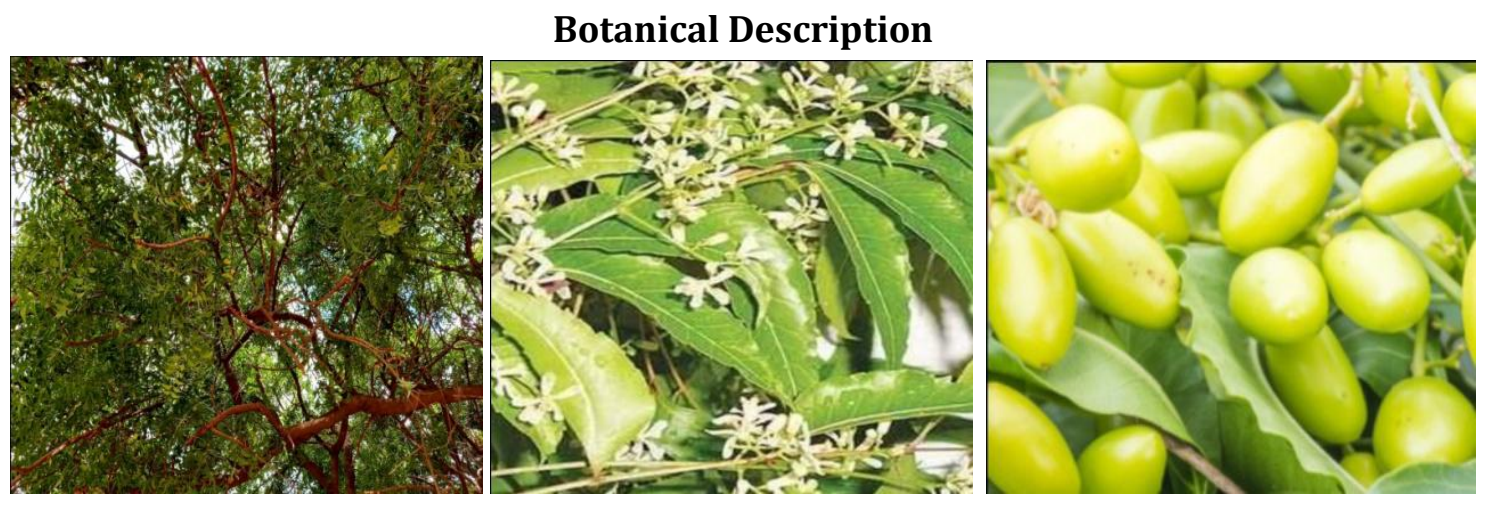


Azadirachta Indica also known as Neem. It is a tree in the mahogany family Meliaceae.

Table 2: Leaf

\begin{tabular}{|l|l|l|}
\hline Kind & Shape & Feature \\
\hline Simple & Alternate & $\begin{array}{l}\text { Leaves alternate, crowded near the end of branches, } \\
\text { simply pinnate, 20-40cm long, light green }\end{array}$ \\
\hline
\end{tabular}

Table 3: Flower

\begin{tabular}{|l|l|l|l|l|}
\hline Type & Size & Color and composition & Stoma & More information \\
\hline Unisexual & $1-2 \mathrm{~cm}$ & Greenish yellow & $5-20$ & Season is June-August \\
\hline
\end{tabular}

Table 4: Fruit

\begin{tabular}{|l|l|l|l|}
\hline Size & Mass & Appearance & Seeds \\
\hline $\begin{array}{l}7-10 \mathrm{~mm} \\
\text { long prone }\end{array}$ & $\begin{array}{l}\text { Fruit 1(max-2) seeded drape, 1-2cm long, } \\
\text { greenish to yellow or purple when ripes }\end{array}$ & $\begin{array}{l}\text { Each about half of the } \\
\text { seeds weight }\end{array}$ & May \\
\hline
\end{tabular}

\section{Chemical Composition}

It contains Nimbandoil, Immobile, Nimocinol, Quercetin and Beta-sitosterol, and two additional tetracyclic tritepenoids zafaral.

\section{Classical Method of Preparation of Pratisaraneeya Teekshna Kshara [12]}

After reviewing all the classical texts, Sushrutas explanation seems to be ideal regarding the preparation of Pratisaraneeya teekshna kshara.

The physician who prepares the Kshara should have a clean bath early in the morning of Sharad ritu in auspicious day. He fasts that day and goes up the hills and looks for such plants which are middle aged and free from insects. The Panchangas of such plants are collected, dried up and made into small pieces. Then these are burnt with limestone. While burning the dispersed parts of the plants are kept with the help of Tilanala. When the ash cools down it should be mixed well with six times of water or cow's urine, then filtered twenty one times in a big vessel through a piece of cloth. The residual portion is thrown away and the filtrate (Ksharodaka) should be kept on Mandagni and continuously stirred well until it turns reddish brown and attain Picchilata or get reduced

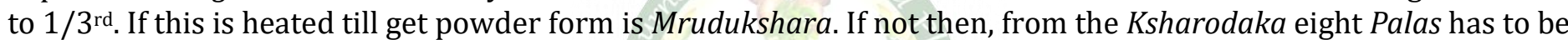
taken and mixed with Shankhanabhi, Shukti and Kata sharkara, each in eight Palas, to make Prativapa. In the meantime, heating should continue Prativapa should be mixed. Care should be taken that it is not too liquid or too dried up. The solution thus obtained is known as Madhyama kshara.

Madhyama kshara should be heated up again by adding some medicinal plants such as Danti, Chitraka with this thick solution is obtained which is known as Teekshna kshara. If Teekshna Kshara losses its potency then it should be mixed with new Kshara and heated again to maintain sufficient concentration.

Table 5: The Physical Characters of Well-Prepared Teekshna Kshara[13-14]

\begin{tabular}{|c|l|c|c|}
\hline S.no & Lakshana & Acharya Sushruta & Acharya Vaghbhata \\
\hline 1. & Na atiteekshna (not too strong) & + & + \\
\hline 2. & Na atimrudu (not too mild) & + & + \\
\hline 3. & Na atishukla (not too white) & + & + \\
\hline 4. & Shlakshna (thin) & + & + \\
\hline 5. & Pichhila (slimy) & + & + \\
\hline 6. & Abhishyandi (unspreading) & + & + \\
\hline 7. & Sheeghrakarita (quick acting) & + & + \\
\hline 8. & Shiva & + & + \\
\hline 9. & Shikari & - & + \\
\hline 10. & Sukha nirvapya & - & + \\
\hline 11. & Alparaktatha & - & + \\
\hline
\end{tabular}

Table 6: The Physical Properties of Improperly Prepared Kshara [15-16]

\begin{tabular}{|c|l|c|c|}
\hline S.no & Lakshana & Acharya Sushruta & Acharya Vaghbhata \\
\hline 1. & Atimrudu (too mild) & + & + \\
\hline 2. & Atiushnata (too hot) & + & + \\
\hline
\end{tabular}




\begin{tabular}{|c|l|c|c|}
\hline 3. & Atishwetha (too white) & + & + \\
\hline 4. & Atiteekshna (too sharp) & + & + \\
\hline 5. & Atipichhila (too Slimy) & + & + \\
\hline 6. & Ativisarpita (too spreading) & + & + \\
\hline 7. & Atisandrata (too thick) & + & + \\
\hline 8. & Apakwata (uncooked) & + & + \\
\hline 9. & Heenadravyata (with less potency) & + & + \\
\hline 10. & Atitanu (too thin) & - & + \\
\hline
\end{tabular}

\section{Probable mode of action of Pratisaraneeya kshara}

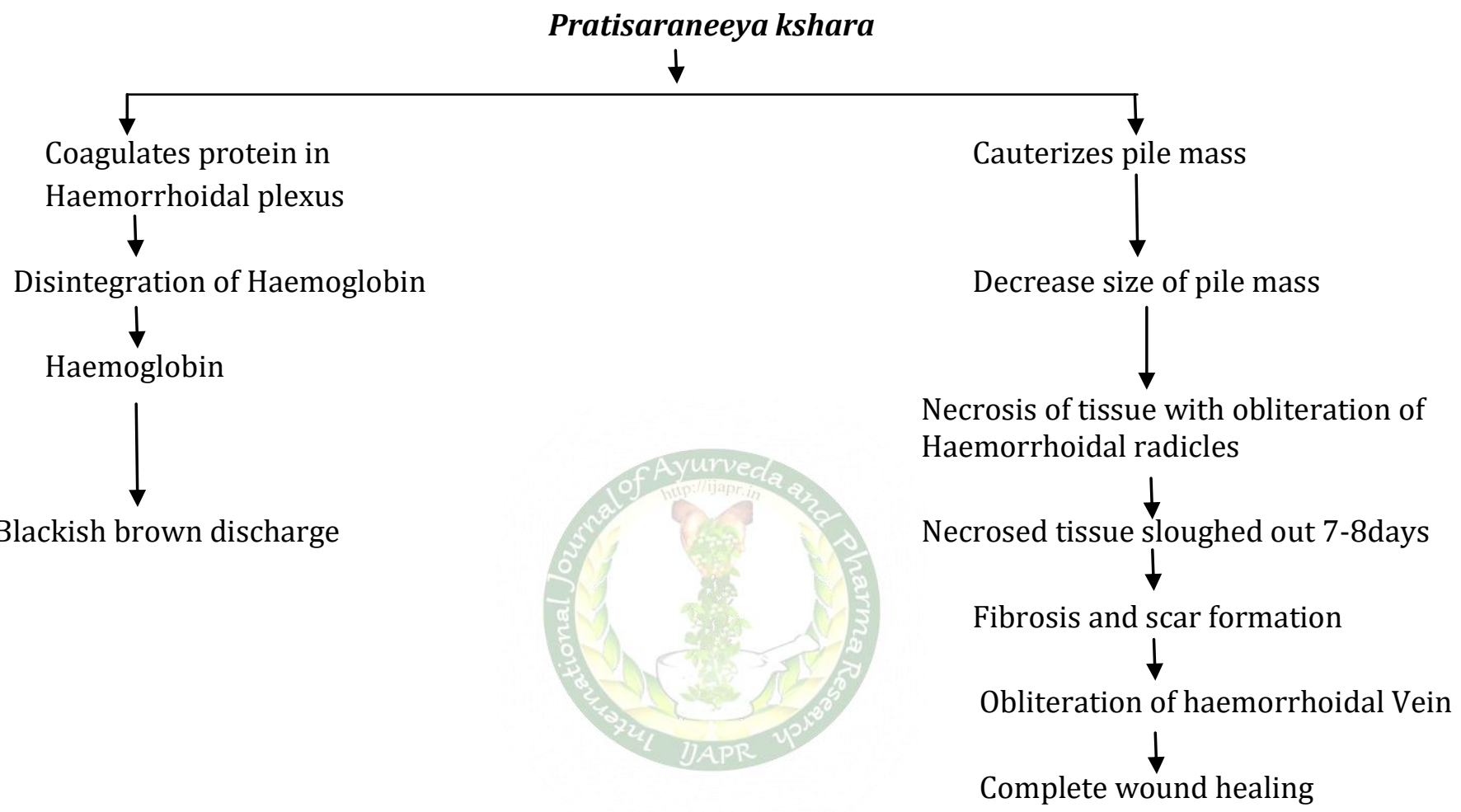

\section{DISCUSSION}

Kshara karma is application of Pratisaraneeya teekshna kshara is a non-surgical procedure of Ayurveda indicated for the management of haemorrhoids. The details of preparation of the herbal combination are mentioned in Sushruta Samhita and Astanga Hrudaya. The superiority of Kshara over Sastras and Anushastras has been mentioned in Sushruta Samhita.

As a result of breaking of pus pockets of unhealthy tissue, pus discharge gets reduces. If pus discharge continues to occur Krimighna property of Nimba is helpful to cure it. The itching is controls by Kandughna property of Nimba and burning sensation gets reduces by Sheeta Virya quality of Nimba. Pus discharge disappeared by quality of Vrana Shodhana in Nimba.

Probable mode of action of Pratisaraneeya teekshna kshara;

Pratisaraneeya teekshna kshara acts on haemorrhoids in 2 ways,
1. It cauterizes the pile mass directly because of its Ksharana guna (corrosive nature)

2. It coagulates protein in Haemorrhoidal plexus.

\section{CONCLUSION}

In Ayurveda, Nimba plays a very important role as a medicine and it plays a very good role in the treatment of ailments and maintaining the health by its anti-inflammatory, anti-arthritic, anti-microbial, Antifungal, anti-bacterial, anti-fertility, immunostimulant activity and exhibits systemic effects also. Ayurveda understands Arshas as a local manifestation of systemic derangement of Doshas and Agni. Therefore almost all the Ayurvedic text books have devoted separate chapter on treatment of the Arshas mostly with the help of different approaches especially para medical procedure like Kshara karma. Nimba is having properties like Sheeta Virya, Tikta and Katu rasa. It is having functions like Chedana, Bhedana and Lekhana can be useful in the management of Ardra arshas. Nimba Pratisaraneeya Teekshna Kshara is safe, cost 
effective, very good haemostatic and successful treatment of internal haemorrhoids with less recurrence. Kshara is Pradhanatama among Shastras and Anushastras. Arshas are found from ancient era, many research works shows it is very effective in obliterating the haemorrhoidal mass within 21 days of application. This study shows that a combination of Kshara karma, Shamanoushadhis and Pathya aharavihara helps in the management of Ardra arshas.

\section{REFERENCES}

1. Kaviraj Ambikadatta Shastri edited Sushrutha Samhita of Acharya Sushruta with Ayurveda tatva sandeepika Hindi commentary, Choukamba Sanskrith Sansthan, Varanasi, Edition, Reprint 2015, Sutra sthana 33/4-5, p-163.

2. Kaviraj Ambikadatta Shastri edited Sushrutha Samhita of Acharya Sushruta with Ayurveda tatva sandeepika Hindi commentary, Choukamba Sanskrith Sansthan, Varanasi, Edition, Reprint 2015, Sutra sthana 6/3, p-46

3. Goligher J, Surgery of Anus, Rectum and Colon, Vol $1, \mathrm{Ch}-4,5^{\text {th }}$ edition, New Delhi, A.I.J.B.S. Publishers and distributors, 2002, P-98.

4. Prof. P.Hemanth kumar, Recent trends in the management of Arsha/haemorrhoids, $2^{\text {nd }}$ edition, ch-1, New Delhi, Choukamba Sanskrith Pratishtana, 2011, P-39.

5. Kaviraj Ambikadatta Shastri edited Sushrutha Samhita of Acharya Sushruta with Ayurveda tatva sandeepika Hindi commentary, Choukamba Sanskrith Sansthan, Varanasi, Edition, Reprint 2007, Sutra sthana 11/12, P-35.

6. J.L.N.Shastry, Dravya guna vignana, Choukamba orientalia, Vol-2, Reprint edition, 2012; 124: 1134.

7. Pandey Gynendra, Dravya guna vignana, part-2, Krishnadas academy, Varanasi, Edition-1, 2001: 691.

8. Lucas Shanth Kumar, Dravya guna vignana, Choukamba vishwabharathi, Reprint Edition, 2015; 2:78.
9. Agnivesha on Charaka Samhita, Sutra sthana, Choukamba orientalia, Varanasi, Edition, Reprint, 2008; $1: 4$.

10. Srikantha Murthy.K.R., Sushruta Samhita, reprint ed. Varanasi; Choukamba orientalia, 2010;1;38.

11. Sharma. P. V., Astanga Hrudaya of Vaghbhata, $10^{\text {th }}$ edition, Varanasi, Choukamba orientalia, 2011;1; 15.

12. Vaidya Yadavji Trikamji Acharya edited Nibanda sangraha commentary of Dalhana Acharya on Sushruta Samhita of Acharya Sushruta, Sutra sthana, ch-11, Shloka-11, published by Choukamba Surbharti prakashana, Varanasi, reprinted, 2014: 824: 46.

13. Vaidya Yadavji Trikamji Acharya edited Nibanda sangraha commentary of Dalhana Acharya on Sushruta Samhita of Acharya Sushruta, Sutra sthana, ch-11, Shloka-16, published by Choukamba Surbharti prakashana, Varanasi, reprinted, 2014: 824:48.

14. Pt.Hari Sadashiva Shastri Paradakara Bhisagacharya edited Arunadatta Acharya commentary Sarvangasundara and Ayurveda rasayana of Hemadri commented on Astanga Hrudaya of Acharya Vaghbhata, Sutra sthana, Ch-30, Shloka- 24, Published by Choukamba Surbharti Prakashana, Varanasi reprinted, 2010; 956; 355.

15. Vaidya Yadavji Trikamji Acharya edited Nibanda sangraha commentary of Dalhana Acharya on Sushruta Samhita of Acharya Sushruta, Sutra sthana, ch-11, Shloka-17, published by Choukamba Surbharti prakashana, Varanasi, reprinted, 2014: 824: 48.

16. Pt. Hari Sadashiva Shastri Paradakara Bhisagacharya edited Arunadatta Acharya commentary Sarvangasundara and Ayurveda rasayana of Hemadri commented on Astanga Hrudaya of Acharya Vaghbhata, Sutra sthana, Ch-30, Shloka- 25, Published by Choukamba Surbharti Prakashana, Varanasi reprinted, 2010; 956; 355.

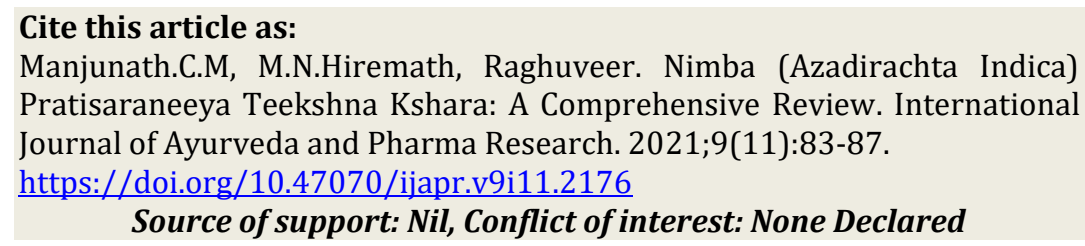

\section{*Address for correspondence Dr. Manjunath.C.M \\ P.G.Scholar, \\ Department of Shalya Tantra, Ashwini Ayurvedic Medical \\ College and P.G.Centre, \\ Davanagere, Karnataka, India. \\ Email: drmanjukplr@gmail.com \\ Ph: 9008844432}

Disclaimer: IJAPR is solely owned by Mahadev Publications - dedicated to publish quality research, while every effort has been taken to verify the accuracy of the content published in our Journal. IJAPR cannot accept any responsibility or liability for the articles content which are published. The views expressed in articles by our contributing authors are not necessarily those of IJAPR editor or editorial board members. 